\title{
Effects of agni karma in the management of gridhrasi - a clinical study
}

\author{
Research Article
}

\section{Namita Baishya ${ }^{1^{*}}$, Pankaj Kalita ${ }^{2}$}

1. Lecturer, Department of Shalya Tantra, Govt. Ayurvedic College, Guwahati, 2. I.M.O.(Ayurveda) E.S.I. Corporaion Model Hospital, Beltola, Guwahati -22, Assam.

\begin{abstract}
Due to alteration in people's life style, the disease Gridhrasi (Sciatica) is frequently seen in the society, as a prominent problem. In this disease, patient becomes incapable to do their daily routine work because of severe pain from Kati-pradesh (lumber region) to Gulfasandhi (ankle-joint). Where the treatment of sciatica is concern, only symptomatic management and a very few surgical procedures are only available in conventional medical science. All these are having their complications and side effects. On the other hand these management tools are not always affordable for the underprivileged section of people in countries like India. In this regard few Ayurvedic para-surgical procedures, which are very effective, simple, safe and cheap in nature can became handy for Ayurvedicians. Agnikarma is one of such procedures. Sushrutacharya mentioned Agnikarma chikitsa in the management of Sira,(Vain), Snayu(Nerve), Sandhi(Joints), and Gridhrasi(Sciatica).

Charakacharya mentioned Agnikarma chikitsa in the management of Gridhrasi(Sciatica) at the site of Antara-Kandara-Gulpha pradesha.

Moreover in Ayurveda various other types of management regarding Gridhrasi (Sciatica) like Snehana, Swedana, and Shamana yoga etc. are also indicated. In the study 18 patients were treated in two groups, one group by Agnikarma therapy and another by Snehanswedana and shaman yoga for a duration of one month. Comparative efficacy was assessed by statistical analysis.

Maximum result was noticed in the group treated with Agnikarma therapy by showing $100 \%$ relief in most of the cardinal features of the disease, and $85 \%$ improvement SLR test.
\end{abstract}

Key words: Gridhrasi, Sciatica, Agnikarma, Snehan, Swedan, Shaman yoga.

\section{Introduction :}

Ayurveda is a complete science of life. Its principles are universally applicable to each individual for daily existence. Ayurveda treasures almost all and every elements and facts of human life offering guidance that have been tested and refined over many centuries to all

*Corresponding Author:

Namita Baishya,

Lecturer, Department of Shalya Tantra, Govt. Ayurvedic College, Guwahati.

Phone No: +918011522100.

E-mail: nomita3@gmail.com those who deserve greater harmony, peace and longevity. The disease Gridhrasi (Sciatica) is commonly seen in society as a prominent problem; in this condition patient become incapable to do his daily routine work because of severe pain from Kati -pradesha (lumbar area) to Padanguli (foot) ${ }^{1}$. As per the treatment of Sciatica is concern, in the conventional medical practice only the symptomatic management and a few surgical procedures are done. All these are having their own complications and adverse reactions. In Ayurvedic texts, there are various method used as a line of treatment, some of which 
are effective, simple, safe and cheap for the patient e.g. Siravedha (Venesection), Agnikarma (kind of cautery), Basti chikitsa (Enema), Snehana, Swedana and oral medication. Charakacharya mentioned Agnikarma-chikitsa in the management of Gridhrasi at the site of Antara-KandaraGulpha pradesha ${ }^{2}$. Sushrutacharya mentioned Agnikarma-chikitsa in the management of Sira, Snayu or Sandhi or Asthi samprapti ${ }^{3}$ and Gridhrasi which may origin involving these structures. Now-adays, Ayurvedic para-surgical procedures like Shastrakarma, Ksharakarma, Raktamokshana procedures are gaining popularity in forthright and conscious society. Many research works have been carried out regarding efficacy of these procedures. Agnikarma chikitsa have yet to gain popularity in society and many Ayurvedicians are far away from scientific approach towards of it, as because very few works have been carried out and there is no pinpoint description about Agnikarma chikitsa elsewhere. That's why keeping view the importance of the disease as well the treatment and above all points, it was decided to carry out Agnikarma chikitsa. Again, as the disease comes under vatik disorder the well-known vatasamak yoga Troyodashanga Guggulu was considered for comparative study.

\section{Metarials \& Methods:}

The clinical study had been carried out exclusively in total 18 patients of Gridhrasi(Sciatica), dividing in two groups - viz.

Group A: Agni Karma 9 patients.

Group B: Troyodashnga Guggulu (orally) + Snehana with Nadisweda - 9 patients. The study was designed as a comparative study to assess the efficacy of two procedures in the management of Gridhrasi.

The study was exclusively based on clinical trials. A detailed Performa was prepared to study the patients as well as the disease. The patients attending the
O.P.D. and I.P.D. of Govt. Ayurvedic College and Hospital, Guwahati were selected irrespective of their age, sex, cast etc.

\section{Criteria for Selection of patient}

Patients were diagnosed mainly on the basis of signs and symptoms available in Ayurveda and modern medicine.

* Ruka, Toda, Stambha, Spandana, ${ }^{4}$

* Sakthanakshepananigrahaniyat ${ }^{5}$

S.L.R. test, Laseuge sign, sitting test in affected leg for diagnosis as well as prognosis of the treatment.

* Local tenderness in lumber region and affected lower limb.

* Knee and ankle jerk.

* Planter flexion test.

* Popliteal compression test.

* Impairment of perception in different dermatome.

* X-ray (A/P view, lateral view of lumbar spine) and routine hematological and other useful test were done to exclude other pathogenesis.

\section{Criteria for Exclusion of patient}

The patient with -

* Pregnancy

* Tuberculosis, Carcinoma of lumbosacral plexus

* Carcinoma of caudaequina

* Uncontrolled Diabetes mellitus etc. were excluded from the present study.

\section{Grouping}

After diagnosis the patients were randomly categorized into two groups as given below.

Group A (Agnikarma) : Agnikarma in different sittings was done In this group. 1st sitting Bindu type Dahana vishesha at Antara Kandara Gulpha Madhya i.e. from mid of medial aspect to the mid of lateral aspect of lower leg, covering the dorsal surface at a height of four angulas from the 
medial melleolus and lateral malleolus till the samyak dagdha lakshana ${ }^{6}$ occurred.

2nd sitting after 15 days at the same site. Continued by $3^{\text {rd }}$ and $4^{\text {th }}$ similar sittings if necessary.

Group B (Troyodashanga Guggulu + Snehan with Mahavisagarva Oil + Nadi Sweda) : In this group, Troyodashanga Guggulu was given 3 gm/day with lukewarm water for 30 days. Snehana with Mahabisagarva oil + Nadisweda with vatanashak drugs up to 14 days were recommended

Agnikarma Chikitsa Vidhi (Procedure):

The entire procedure consists three parts.

- Purva karma (Pre-operative procedure)

* Pradhana karma (Operative procedure)

* Paschat karma (Post-operative procedure)

\section{Purva Karma (Pre-operative \\ Procedure):}

The shalya karma mandir (Operation theater) was readily arranged. Preparation of the patient's local parts i.e. removing of hair (shaving), preparation of Shalya Chikitsaka(Surgeon) and Paricharika (Nurses) were observed. The Shalaka, Prota (gauze), Pichu (cotton), Gas stove, Triphala Kashaya, Swab holding forceps, Kumari Swarasa, Yashtimadhu churna were kept ready for use. Patients were advised for Snigdha and Picchila light diet before Agnikarma chikitsa. Written consent of were taken from the each patients.

The Shalaka was heated to red hot on fire. The patients were put on the Shalya karma Mandir Shayya and the diseased parts were cleaned with Triphala kashaya. Use of spirit was strictly avoided because it can catch fire.

\section{Pradhana Karma \\ Procedure): \\ (Operative}

The affected leg of the patient was seen and at the site of 4 Angula (finger)above of Gulpha sandhi (Ankle joint)on posterior side of affected leg, 5 30 bindu size (bindu dahana vishesha), Samyaka dagdha vrana were produced in the form of Vilekha by red hot Loha dhatu Shalaka. The proper space between two Samyaka dagdha vrana was kept.

\section{Paschat Karma (Post Operative Procedure):}

After producing Samyaka Dagdha Vrana, the Kumari Swarasa was applied on samyaka dagdha vrana to get relief from burning sensation and after wiping of Kumari Swarasa, Avachurnan (dusting) of Yashtimadhu churna was done on Samyaka Dagdha Vrana and from next day patients were advised for local application of an ointment made of Haridra powder mixed with coconut oil. Pathya-pathya advised as per Sushrutacharya's Vrana Rogadhikara until healing of Samyaka Dagdha Vrana.

\section{Criteria for Assessmen:}

The improvement in each patient was assessed mainly on the basis of relief in the cardinal signs and symptoms of the disease. To assess the effect of therapy objectively, all the signs and symptoms were given scoring depending upon their severity as below.

\section{Stambha (Stiffness)}
i. No stiffness - 0
ii. Some time for 5-10 min. - 1
iii. Daily for 10-30 min. - 2
iv. Daily for 30-60 min. - 3
v. Daily more than 1 hour -4 
2. Ruka (Pain)

i. No pain - 0

ii. Occasional pain - 1

iii. Mild pain - 2

iv. Moderate pain - 3

v. Severe pain -4

\section{Toda (Pricking Sensation)}

i. No pricking sensation - 0

ii. Occasional pricking sensation - 1

iii. Mild pricking sensation - 2

iv. Moderate pricking sensation - 3

v. Severe pricking sensation - 4

\section{Spandana (Twitching)}

i. No twitching - 0

ii. Some times for 5-10 min. - 1

iii. Daily for 10-30 min. - 2

iv. Daily for 30-60 min. - 3

v. Daily more than 1 hour -4

5. Aruchi (Anorexia)

i. No anorexia - 0

ii. Mild anorexia - 1

iii. Moderate anorexia - 2

iv. Severe anorexia -3

6. Tandra (Torpor)

i. No tandra - 0

ii. Mild tandra - 1

iii. Moderate tandra - 2

iv. Severe tandra -3

7. Gaurava (Heaviness)

i. No heaviness - 0

ii. Mild heaviness - 1

iii. Moderate heaviness - 2

iv. Severe heaviness -3

8. Straight leg raise test

i. More than 900 - 0

ii. $710-900-1$

iii. $510-700-2$

iv. $310-500-3$

v. up to $300-4$

\section{Statistical analysis:}

Mean, percentage, \pm S.D., \pm S.E. ' $t$ ', and ' $p$ ' value were calculated. Paired ' $t$ ' test was used for calculating the ' $t$ ' value.

Criteria for assessing the total effect:

Considering the overall improvement shown by the patients in sign and symptoms. The total effect of the therapy has been assessed as below -

1. Cured - $100 \%$ relief in sign and symptoms

2. Markebly Improved - More than $50 \%$ relief in signs and symptoms

3. Improved - $25-50 \%$ relief in signs and symptoms

4. Unchanged - below $25 \%$ relief in signs and symptoms

\section{Observation \& Results}

The following results was found after completion of the procedure Majority of the patients belonged to the age group of 41-60 $\mathrm{yrs}(55.6 \%)$, were predominantly males(66.7\%), Hindus(77.8\%), belongs to labour class \& housewives(55.6\%), married(100\%), belongs to lower middle class of society $(83.3 \%)$, previously treated(66.7\%)types of disease was vataja $72.2 \%$, followed by $27.8 \%$ in vatakaphaja, prakritti vata kaphaja77.8\%. In $88.9 \%$ patients, tenderness at sciatic root is present. $66.7 \%$ patients were having highly positive foot flexion test. Diminished ankle jerk was present in $33.3 \%$ patient and $20 \%$ diminished knee jerk was present in $27.8 \%$ patients. Stambha, Ruka, and Toda were present in $100 \%$ patients while spandana was present in $77.7 \%$ patients. Gourava was present in $44.4 \%$ patients. Aruchi was present in $38.9 \%$ patients while Tandra was present only in $11.1 \%$ patients. SLR test as positive was present in $10 \%$ of patients. 
Results of Therapy:

Effect of Therapy on Cardinal Symptoms of Gridhrasi

Group - A: Agni Karma

\begin{tabular}{|c|c|c|c|c|c|c|c|c|c|}
\hline \multirow{2}{*}{$\begin{array}{l}\text { S1. } \\
\text { No. }\end{array}$} & \multirow{2}{*}{$\begin{array}{l}\text { Cardinal } \\
\text { Symptoms }\end{array}$} & \multirow[t]{2}{*}{$\mathrm{n}$} & \multicolumn{2}{|c|}{ Mean Score } & \multirow[t]{2}{*}{ \pm SD } & \multirow[t]{2}{*}{$\pm \mathbf{S E}$} & \multirow[t]{2}{*}{ ' $t$ ' } & \multirow[t]{2}{*}{$\mathbf{p}$} & \multirow[t]{2}{*}{$\%$} \\
\hline & & & B.T. & A.T. & & & & & \\
\hline 1. & Stambha & 9 & 1.4 & 0 & 0.53 & 0.17 & 8.235 & $<0.001$ & $100 \%$ \\
\hline 2. & Ruka & 9 & 2.3 & 0 & 0.87 & 0.29 & 7.931 & $<0.001$ & $100 \%$ \\
\hline 3. & Toda & 9 & 1.4 & 0 & 0.53 & 0.17 & 8.235 & $<0.001$ & $100 \%$ \\
\hline 4. & Spandana & 8 & 1.25 & 0.125 & 0.35 & 0.125 & 9.000 & $<0.001$ & $90 \%$ \\
\hline 5. & Aruchi & 4 & 1.0 & 0.75 & 0.50 & 0.25 & 1.000 & $>0.10$ & $25 \%$ \\
\hline 6. & Tandra & 2 & 1.0 & 0.50 & 0.70 & 0.50 & 1.000 & - & $50 \%$ \\
\hline 7. & Gaurava & 4 & 1.0 & 0.00 & 0.00 & 0.00 & $\mathrm{E}$ & - & $100 \%$ \\
\hline 8. & SLR test & 9 & 2.22 & 0.33 & 0.78 & 0.26 & 7.326 & $<0.001$ & $85 \%$ \\
\hline
\end{tabular}

Group - B : Trayodashanga Guggulu with Snehan with Mahavisargarva Oil + Nadi Sweda

\begin{tabular}{|c|c|c|c|c|c|c|c|c|c|}
\hline \multirow{2}{*}{$\begin{array}{l}\text { Sl. } \\
\text { No. }\end{array}$} & \multirow{2}{*}{$\begin{array}{l}\text { Cardinal } \\
\text { Symptoms }\end{array}$} & \multirow[t]{2}{*}{$\mathrm{n}$} & \multicolumn{2}{|c|}{ Mean Score } & \multirow[t]{2}{*}{ \pm SD } & \multirow[t]{2}{*}{$\pm \mathbf{S E}$} & \multirow[t]{2}{*}{ 't' } & \multirow[t]{2}{*}{ p } & \multirow[t]{2}{*}{$\%$} \\
\hline & & & B.T. & A.T. & & & & & \\
\hline 1. & Stambha & 8 & 1.37 & 0.12 & 0.46 & 0.16 & 7.812 & $<0.001$ & $90.90 \%$ \\
\hline 2. & Ruka & 9 & 2.33 & 0.11 & 0.67 & 0.22 & 10.09 & $<0.001$ & $95.27 \%$ \\
\hline 3. & Toda & 9 & 1.44 & 0.11 & 0.50 & 0.165 & 8.060 & $<0.001$ & $92.36 \%$ \\
\hline 4. & Spandana & 6 & 1.17 & 0.00 & 0.40 & 0.17 & 7.02 & $<0.001$ & $100 \%$ \\
\hline 5. & Aruchi & 3 & 1.33 & 0.00 & 0.58 & 0.33 & 3.99 & $>0.01$ & $100 \%$ \\
\hline 6. & Tandra & 0 & 0 & 0 & 0 & 0 & 0 & 0 & $0 \%$ \\
\hline 7. & Gaurava & 4 & 1.25 & 0.00 & 0.50 & 0.25 & 5.00 & $>0.001$ & $100 \%$ \\
\hline 8. & SLR test & 9 & 2.22 & 0.67 & 0.89 & 0.29 & 5.325 & $<0.001$ & $69.8 \%$ \\
\hline
\end{tabular}

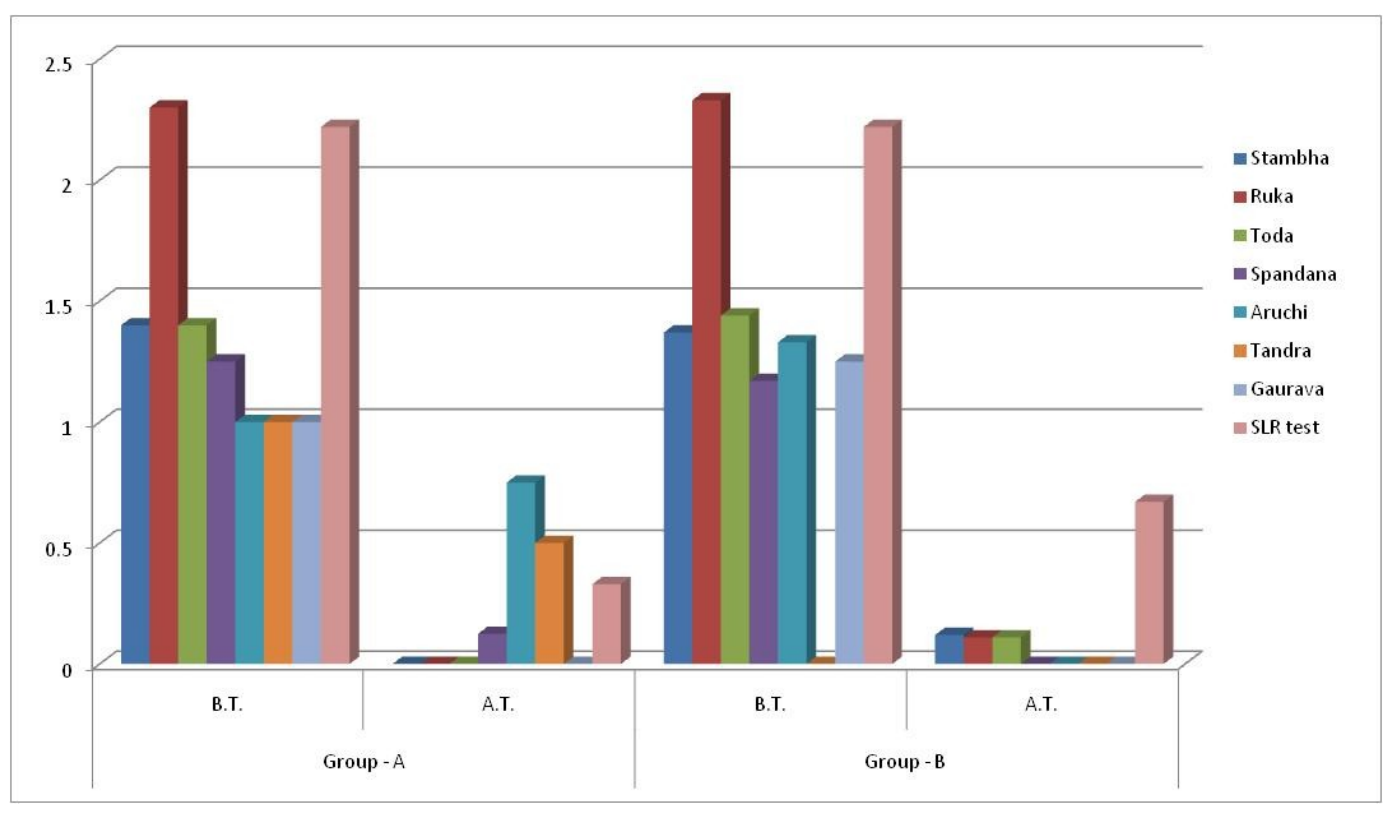




\section{Comparative study of Results in both groups}

\begin{tabular}{|l|l|c|c|}
\hline \multirow{2}{*}{$\begin{array}{l}\text { Sl. } \\
\text { No. }\end{array}$} & \multirow{2}{*}{ Cardinal Symptoms } & \multicolumn{2}{|c|}{ Results in \% } \\
\cline { 3 - 4 } & & Group - A & Group - B \\
\hline & Stambha & 100.00 & 90.90 \\
\hline 3 & Ruka & 100.00 & 95.27 \\
\hline 4 & Toda & 100.00 & 92.36 \\
\hline 5 & Spandana & 90.00 & 100.00 \\
\hline 6 & Aruchi & 25.00 & 100.00 \\
\hline 7 & Tandra & 50.00 & 0.00 \\
\hline 8 & Saurava & 100.00 & 100.00 \\
\hline
\end{tabular}

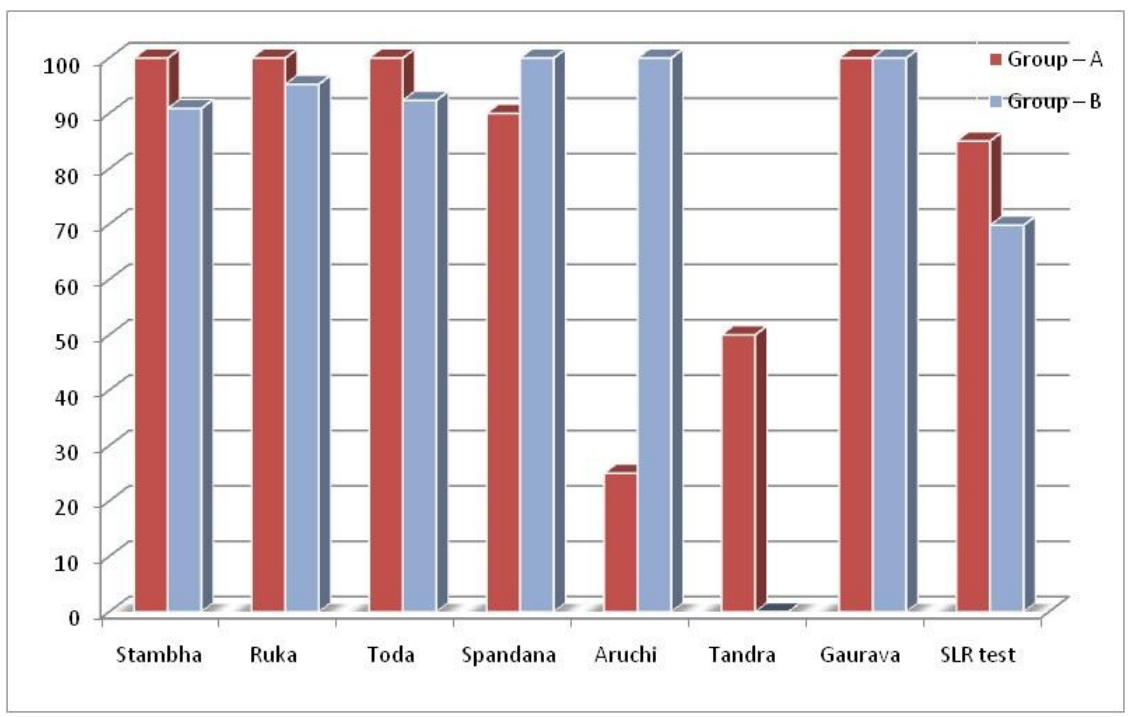

\section{Comparative study of overall effect of therapy in both groups}

\begin{tabular}{|l|c|c|}
\hline Effect & Group - A & Group - B \\
\hline Cured & $44.44 \%$ & $44.44 \%$ \\
\hline Markedly Improved & $55.56 \%$ & $55.56 \%$ \\
\hline Improved & $0.00 \%$ & $0.00 \%$ \\
\hline Unchanged & $0.00 \%$ & $0.00 \%$ \\
\hline
\end{tabular}

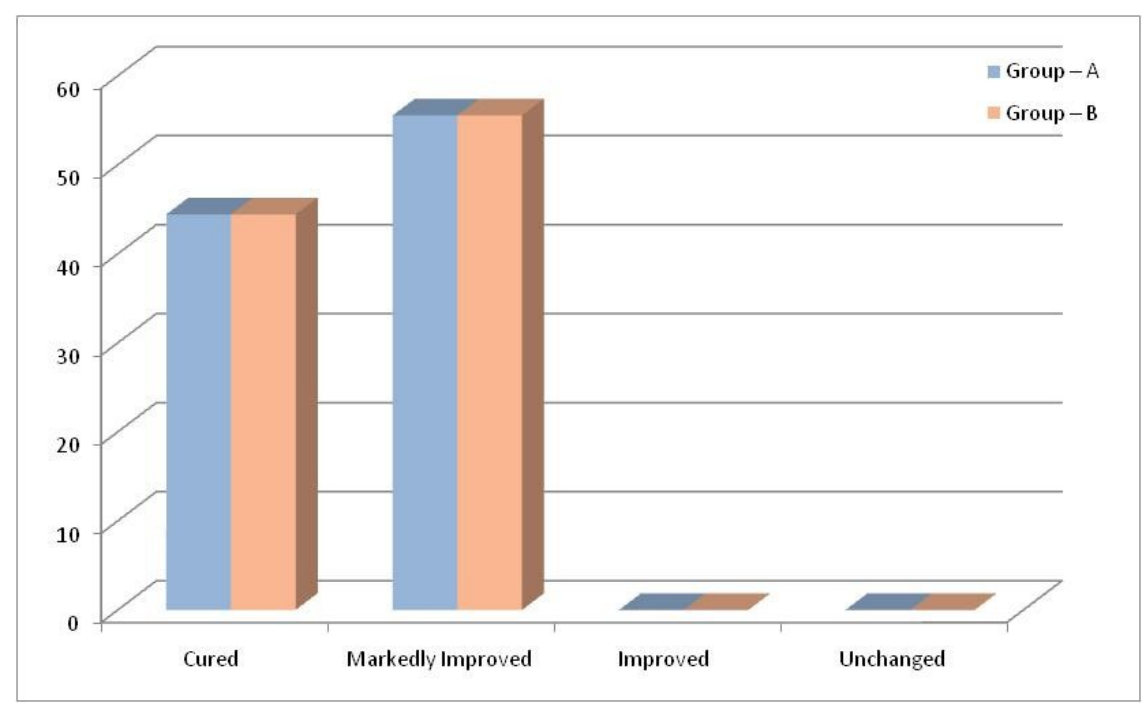




\section{Follow Up:}

During the period of follow up (6 months) results were found at a standstill.

\section{Discussion:}

The pharmacodynamics of a therapy depends on its property like Rasa, Guna, etc. in term of Ayurveda. It is primarily the Doshashamaka activity, which is used to correct the vitiated Dosha to reinstate the Tri-Doshik equilibrium i.e. the main aim of therapy. Agni Karma is stated as the ultimate therapy for those disorders which are not curable with other measure. ${ }^{7}$

Analysis of general Samprapti of Gridhrasi(Sciatica) reveals that mainly Vyana Vata plays a major role in manifestation of disease and this is also supported by Harita's statement that Gridhrasi is result of vitiation of Vyana Vata. Here one thing is again noteworthy that Acharya Charaka and Acharya Sushruta have stated that when Kapha masks Vyana Vata, it gives rise to frequent restricted movement ${ }^{8}$ ( $\mathrm{Su}$. Ni. 1/39), that's why Kapha plays a role as Anubandha in manifestation of disease Gridhrasi. Kandara of Parsni and Pratyanguli have been stated as adhisthana of disease Gridhrasi (Sciatica). ${ }^{5}$

Hence, when Agni Karma is done at four angula above the Gulpha (ankle joint $)^{2}-($ Ch. Chi. - 28) then by virtue of it's Ushna, Tikshna, Sukshma guna it breaks the avarana of Vyana Vata by Kapha and release the Vata to perform its normal functions, thus Stambha, Ruka and Toda like symptoms get subsided. Here, disease Gridhrasi(Sciatica) should be considered as a Prakriti Samvet Samanvaya Vyadhi that means clinical features as just similar to Vyadhi Utapatikaraka Bhava (causative factor of disease). Hence, to break that DoshDushya samurchhana, Agni Karma is an ideal modality of treatment for Gridhrasi (Sciatica).

\section{Probable Mode of Action of Agnikarma Therapy:}

When a red heated Agnikarma Shalaka is applied over skin tissue for Samyaka dagdha, heat is transferred from Shalaka to skin tissue in the form of Ushna, Tikshna, Sukshma and Laghu guna. Ushna guna performs two functions. Firstly by stimulating i.e. Utkleshana of Dhatvagni removes Ama from the dhatu by the process of Dhatupaka. Secondly Ushna guna dilates the channels of Srotas and Srotavarodha is removed. Thus the symptom of the disease is relieved.

\section{Conclusion:}

* Gridhrasi(Sciatica) is commonly seen in society as a prominent problem.

* Number of sittings of Agnikarma depends upon the chronicity and severity of the disease.

* Overall, Agnikarma is simple modality of treatment, having no complication.

* Gridhrasi can be absolutely cured by Agnikarma chikitsa.

\section{References:}

1. Kasinanatha Sastri, The Charak Samhita of Agivesa, Vol II, Reprint edition, new Delhi, Chaukhambha Publication, 2006, Page 700.

2. Vaidya Jadavji Ttrikamji Acharya, Charak Samhita by Agnivesa, Reprint edition, Varanasi, Chaukhambha Prakashan, 2007 , Page 621.

3. Prof. K. R. Srikantha Murthy, Illustrated Susruta Samhita, Vol-I, Edition $2^{\text {nd }}$ Varanasi, Chaukhambha Orientalia, 2004, Page 72

4. Kasinatha Sastri \& Dr. Gorakhanatha Chaturbedi, The Charak Samhita of Agnivesa, Vol II, Reprint edition, Varanasi, Chaukhambha Visvabharati 2007 , Page 787.

5. Kaviraj Dr. Ambikadutta Shastri, Ayurveda Tatvasandipika, Hindi vyakshya,Susrut Samhita of SushrutPurvardha, Edition $11^{\text {th }}$.Varanasi, 
Chaukhambha Snaskrit Bhavan, 1997, Page 234.

6. Prof. K. R. Srikantha Murthy, Illustrated Susruta Samhita, Vol-I, Edition $2^{\text {nd }}$ Varanasi, Chaukhambha Orientalia, 2004, Page 71

7. Vaidya Jadavji Trikamji Acharya and Narayan Ram Acharya, Susruta Samhita of Susruta with Niibandha
Sangraha Commentary, Edition $8^{\text {th }}$, Varanasi, Chaukhambha Orientalia, 2005, Page 12.

8. Kaviraj Dr. Ambikadutta Shastri, Ayurveda Tatvasandipika, Hindi vyakshya,Susrut Samhita of Sushrut Purvardha, Edition $11^{\text {th }}$.Varanasi, Chaukhambha Sanskrit Bhavan, 1997, Page 231. 